\title{
IMPROVING THE EFFICIENCY OF CASH COLLECTION OPERATIONS WITH THE HELP OF MODERN INFORMATION TECHNOLOGIES
}

\author{
Andriy Fedets \\ Educational and Scientific Institute of Public Administration \\ Lviv Polytechnic National University \\ 16 Suhomlynksyy Street, Lviv-Bryuhovychi, Ukraine, 79491 \\ Department of Transportation of Valuables in Lviv Region \\ Central Depository of the National Bank of Ukraine \\ avflviv@gmail.com
}

\begin{abstract}
Despite the steady spread of non-cash payment technologies, especially now in the pandemic, cash remains the most common method of payment in all countries.

The availability of cash in banking institutions, cash centers, ATMs, various self-service devices is provided by the units of collection and transportation of currency values.

Collection of funds and transportation of currency values is an integral part of the cash circulation of any banking system, which consists in the collection, delivery and movement of cash by vehicles, from enterprises, institutions, organizations of various forms of ownership to banking institutions and vice versa.

The cost of conducting cash collection, supporting cash registers, branches, and loading ATMs constitues a significant part of all operating expenses of banks and collection companies. Due to the high level of risk of attacks on the teams of collectors, the main task is to maintain an appropriate level of security to protect life and health of collectors, which requires significant financial costs. Business owners find a way out in the introduction of new innovative banking products and information technologies.

The article examines the processes of cash collection operations by classical and electronic methods as well as modern innovative technologies for cash collection, cash processing, and protection of valuables. The results of scientific research show that the reduction of operating costs for cash collection increases the level of security, and optimization of cash processing is possible only with the active implementation and use of modern information technology and automated software.

The article proves the need to improve the mechanism of state regulatory policy in the market of cash collection services in Ukraine, in particular, to amend the regulatory legal acts of the regulator, which is represented by the National Bank of Ukraine, in terms of refining and detailing legal norms that establish and determine the procedure operations on cash collection in electronic form and periodicity of collection units employees training.
\end{abstract}

Keywords: information technologies, state regulatory policy, electronic collection, Cash-in-Transit.

DOI: 10.21303/2504-5571.2021.002078

\section{Introduction}

It's hard to imagine a modern society without information technology. Every year, modern information technology becomes one of the most profitable and fast-growing sectors of the national economy.

The banking system is no exception in the active introduction of modern information technologies. The main tools and IT solutions, used by a banking institution, directly determine the efficiency of its operational activities [1].

The study of current trends in the development of information technology, the main directions of modernization of the information infrastructure of banking institutions, in particular, the direction of collection of cash and transportation of valuables is relevant and important for the formation of their business strategies.

To minimize the risks, associated with meeting the needs of the national economy concerning cash and record growth rates of cash in circulation, despite the increase in the total number of non-cash payments during the global pandemic, solving problems of effective state regulation of the collection services market, acquire the level of ensuring the national security of the country. 
In a market economy, the central bank is a key element of the monetary system of any developed country and acts as the main body of state regulation of macroeconomic processes through monetary methods.

Under modern conditions, the activities of the central bank have a decisive impact on the stability of the currency, the reliability of banking institutions, the organization and operation of cash circulation, cash collection operations and transportation of valuables.

The model of organization of cash circulation in the state is determined by the degree of organizational and functional involvement of its central bank in the main processes of organization of cash circulation: design development and production of banknotes; storage, issue and distribution of cash; control and regulation of money circulation; processing of cash to ensure its quality and authenticity, destruction of banknotes and coins that are unusable.

In international practice, it is accepted to consider three main types of operating models (centralized, partially delegated), in which the duties and responsibilities of the main participants in cash differ depending on the strategy, implemented by the central bank and the interaction between the central bank, its partners and the population, cash circulation cycles [2].

Depending on the type of operating model of cash flow organization, implemented by the central bank, the following subdivisions of cash collection and transportation of valuables (hereinafter-subdivisions of cash collection) may be formed and function:

1) collection units of the central bank of the country,

2) collection units of banking institutions;

3) Cash-in-transit (CIT) - private collection companies.

Recent trends in the market for collection services show, however, that banking institutions, trying to optimize their costs, continue to close their collection units and move to service to more powerful players in the collection market. For example, in the collection market in Ukraine, unfortunately, there are no powerful transnational collection CIT companies, the market is controlled mainly by the collection units of a number of systemic banks of Ukraine and powerful domestic collection companies.

A number of unresolved issues common to all collection units that have accumulated in national markets for collection services, mainly related to the absence or imperfection of existing legislation, including its effective regulatory function, require thorough analysis and study of innovative foreign experience, organization of collection, its balanced and selective application.

For all collection companies, working in the field of collection services, the issue of ensuring a high level of security is critical in conducting collection operations and developing relationships with customers.

Maintenance of collection units requires from the owners of collection companies quite serious investment in this type of business, given that only the cost of one collection armored car III -class of protection against damage (must be at least 2 cars) reaches tens of thousands euro, and also need to have certified cash register, cash register equipment, highly qualified trained personnel, equipped with weapons, bulletproof vests, car tracking systems, special cases with the use of intelligent banknote neutralization systems, reliable communication, uniforms, equipment, etc.

Reduced operating costs for collection funds are sought not only by the owners of collection units but also by the collected business entities.

The way out of this situation, business owners are looking for the introduction of new innovative banking products and information technology, including the use of modern software that will fully automate the processes of cash processing, recalculation, verification, packaging, collection and transportation.

Leading banks in the operations of electronic collection, the introduction of technical innovations are significantly ahead of their counterparts, who still continue to collect the classical method.

Aim of the article is to substantiate, improve methods and mechanisms to increase the efficiency of cash collection operations with innovative banking products and modern information technologies, the practical implementation of which will reduce operating costs for collection, 
ensuring a high level of safety and health of collectors and transportation of valuables, optimization of cash processing.

\section{Materials and Methods}

The following methods were used in this research: functional - to identify and justify approaches to understanding the organizational and legal principles of the state regulatory policy of the National Bank of Ukraine in the matter of collection operations; comparison - to compare the classical and electronic methods of collection, forecasting - to develop proposals for adopting a positive foreign collection experience; abstract (theoretical generalizations and development of an organizational and legal mechanism for improving public administration of a state body). The system method and the generalization method were used to formulate the conclusions of the study.

\section{Result and Discussion}

The National Bank of Ukraine (hereinafter-the National Bank), as a leading state banking institution, according to paragraph 17 of Article 7 of the Law of Ukraine "On the National Bank of Ukraine" establishes rules and regulations that determine the procedure for collection of cash and transportation of currency (hereinafter-collection) in banking institutions in Ukraine, issues licenses for the right to collect cash and transport banknotes and coins and other valuables as well as exercises state regulatory control over compliance with the rules and procedures for conducting collection operations in banking and non-banking institutions in Ukraine [3].

Moreover, in accordance with paragraph 7 of Article 7 of the abovementioned law, the National Bank determines the development of modern electronic banking technologies, ensures continuous, reliable, and efficient operation of payment and accounting systems, controls the creation of payment instruments, banking automation systems, and means of protection of banking information [3].

The National Bank performs the key functions of public administration for the banking system of Ukraine, in particular: organization of cash circulation; exclusive right to produce and store banknotes and coins; establishment of rules for issuance, processing, storage, collection, transportation, withdrawal from circulation and destruction of cash [3].

The goals of state regulation also include issues, related to the organization of cash collection by banks and legal entities, compliance with mandatory norms and requirements for ensuring reliable protection of life and health of employees of units of collection and transportation of valuables (hereinafter-collection units), the safety of valuables that are transported and collected.

In accordance with paragraph 16 of the Regulation on cash transactions in the national currency in Ukraine, approved by the Board of the National Bank of Ukraine dated December 29, 2017, № 148, on the day of its receipt cash in the full amount is handed over to the bank by the businesses entity independently or through appropriate services, which according to the law have the right to cash collection [4].

All cash that remains in the cash register of the business entity at the end of the business day and was not handed over is considered over-limit, if the business entity has not set a cash limit.

Heads of institutions/enterprises are responsible for compliance with the regulations on the establishment of the cash limit and for the accuracy of the relevant indicators, specified in the calculation of the cash balance limit [4].

The market of collection of cash and transportation of valuables (hereinafter-the collection market) is one of the most closed segments of the banking system of any country. This applies both to the information component of this market and to its openness, as well as to the emergence of new participants, due to the specifics of providing collection services that require the highest degree of confidentiality and security in order to protect the lives and health of employees.

Currently, the main regulatory act that defines the requirements for the procedure of cash collection in Ukraine is the Instruction on the organization of collection of cash and transportation of currency in Ukraine, approved by the Board of the National Bank of Ukraine dated March 31, 2017 No. 29 as amended (hereinafter-Instruction №29) [5]. 
Collection of cash and transportation of valuables is an integral part of the current system of cash circulation of the banking system of Ukraine, which consists in receiving valuables from customers on the basis of relevant contracts and delivering them to the bank or to the cashier of the cash collection company that is responsible for its processing and storage, or receiving valuables from the bank's divisions [5].

Cash collection in Ukraine is carried out by collection units of banking institutions and legal entities in accordance with the requirements of the National Bank. In case of violation of the rules and procedure for the cash collection operation, the relevant measures, provided by the National Bank, are taken [5].

The general trend of the market of cash collection services in Ukraine in recent years shows, however, that banking institutions are trying to optimize their costs, and thus, continue to close their own collection units and start using services, provided by more powerful players in the market. At the same time, in the collection market in Ukraine, unfortunately, there are no powerful transnational collection CIT companies. The market is controlled mainly by the collection units of a number of banks of Ukraine and powerful domestic collection companies.

What concerns electronic collection and introduction of technical innovations, leading Ukrainian banks are significantly ahead of their colleagues, who still continue to carry out by the classical method.

Due to the rapid development of digital technologies and the latest amendments to Instruction No. 29, the National Bank provided for the possibility of using paper as well as electronic IDs and/or ID cards, the use of advanced electronic signature and advanced electronic seals when working with electronic documents [5].

There is no detailed procedure on how the collection should be carried out and there is no description of collection operations in the Instruction No. 29 - the regulatory act is quite concise and limited in terms of defining the process of collection, including electronic collection, online collection, allowing collection units to determine their own requirements and procedure for conducting this operation [5].

Regulatory and legal norms of the regulatory act do not fully cover the requirements for information security, information protection, electronic collection process, self-collection and thus create risks of failure to protect the life and health of employees of collection units, loss of valuables, decrease in quality of inspections of collection units by the regulator.

The use of the latest information technologies in collection operations reflects another problematic issue of the collection market, namely the gaps and shortcomings in the system of training of employees of collection units. Due to dynamic changes in the industry, the current norm of periodic training of employees of collection units every 5 years has catastrophically lost its relevance and needs to be reviewed as soon as possible in terms of reducing this period at least to the annual training [5].

Collection bags, lead seals, and paper transactions will soon become a history; in order to carry out electronic collection, work with the latest types of ATMs, special devices for storing valuables, software, and smartphones, collectors need to constantly acquire new professional knowledge, learn how to work with modern information technologies and improve their skills.

When carrying out cash collection by the classical method, a team of collectors with or without security depending on the amount of cash to be collected, on the armored vehicle conducts a detour of a number of collection points (place of trade or provision of services) according to a predetermined main or reserve route.

For each client a relevant document is created, indicating the client's name, collection route, numbers of bags to be transported, date and time of collection, and the amount of cash in the bag. The responsible person of the client (cashier) must certify with his/her signature the information about each collection.

Each client is given the required number of collection bags with the name of the corresponding collection unit, indicated on them. The client submits to the collection unit samples of the seal, with which the collection bags with cash are sealed for control purposes during the collection process. The collection unit makes a schedule of arrival of collectors to clients. A team of collectors is 
assigned to each collection route. One of the members of the collection team is appointed as the head of the collection team, the other one is the collector [6].

The head of the collection team, before accepting the bag with cash, presents to the cashier of each collection point his/her ID card with a photo, report card, and other documents.

The cashier of the client, upon handing over bags with cash to collectors, draws up an accompanying cash order for each bag. The collector checks the identity of the sample seal, the correspondence of the number of the bag that he/she accepts the number, indicated in the report card and in the accompanying cash order, the date, signatures of authorized employees of the client, correspondence of the amount of cash, indicated in the report card, to the entries in the accompanying cash order, the presence of the cashier's signature. After that, the collector signs the accompanying cash order, indicates the date, and puts a stamp with the route number. All documents, required for collection, including waybills, are created mainly with the help of computer, printed, signed by responsible persons, certified by seals and stamps.

At the cash center, the cash, delivered by the collectors, is checked and after that the next day the corresponding amount is credited to the client's current account in the banking institution.

From the above description of the collection process, we can conclude that the collection via the classical method refers to high-risk transactions, it takes a lot of time, resources of collection units and allows customers to access funds in their current account only on the next banking day.

In order to compare the two methods of collection, let's consider the electronic method of collection of funds. According to this method, in order to carry out collection, the client must enter into a contract for collection services in electronic form with the relevant collection unit, have a current account in the bank, and be connected to the online banking system.

On the basis of the concluded contract, the collection unit performs cash collection or online collection of the client's sales unit, collects funds at the client's cash desks, delivers the client's funds to the cash desk of the collection unit for further recalculation and crediting to the client's current account.

To carry out collection, the client shall submit a corresponding request in advance via online chat or by phone. The collection unit provides each customer's sales unit with the required number of safe packages (collection bags). Safe packages (hereinafter-packages) have a unique QR-code, which can be scanned by the collector's smartphone via a special application for collection [6].

Prior to putting cash in the package, the client should fill in the accompanying cash order at the POS terminal for each package and sign each copy, then seal the package with cash with a protective tape and hand it to the collector only after checking his/her electronic identity card with a photo on the smartphone of the collector.

Prior to putting cash in the package, the client should issue the accompanying cash order for each package. After checking the integrity of the cash package, the client confirms the collection by scanning the QR code of the package; the data is transmitted to the electronic report card and stored in the database of the collection unit. Upon receipt of the package, the collector signs the accompanying cash order (check is generated by the POS terminal), puts a route stamp, and returns it to the client [6].

The electronic collection procedure provides for mandatory electronic confirmation (via the POS-terminal, installed at the client or the mobile terminal of the collector) of the fact that the client has transferred a package with revenue to the collector. An accompanying cash order is generated on the basis of the data, entered by the client using a POS terminal with mandatory confirmation of the entered data using the client's personal mobile phone number. The client's mobile phone number is entered into the database of the collection unit as a number that is authorized to confirm the collection process.

The delivered funds are credited to the client's account according to the details, specified in the collection agreement. The collection unit performs recalculation of the revenue and credits it to the client's current account by 11:00 on the next business day after the collection.

The online collection technology means crediting the revenue to the client's current account online immediately after the actual collection by the collection team. 
By connecting to the online collection technology, the client gets real-time account management. Online collection is available to the client, provided he/she has an account in this banking institution.

Upon conducting online collection, the client instructs the collection unit to debit funds from his/her current account in the national currency of Ukraine, which is credited collected revenue in the amount, specified in the act of disagreement, by issuing a memorial order.

In the case of online collection, revenue is credited to the client's current account within the previously set limit within 10 minutes after the actual transfer of the client's safe package with revenue. The collection process itself is very quick and takes up to 1 minute, which allows servicing more collection points on one route [6].

Automated software packages for cash centers, in addition to cash processing products include collection modules (CIT), mobile applications for online collection, which allow to optimize the human resources of collection units, reduce operating costs for operational armored vehicles, as well as to reduce fuel costs and consumables in cash logistics.

Software solutions enable collection units to fully automate a significant part of the process of loading cash into ATMs, form teams of collectors, collection routes, keep track of all costs, associated with operating activities, predict the cost of all collection orders, working hours, and distance to each collection point [7].

Modern software, in particular the software and hardware complex "Avtokasa", which is popular in Ukraine, allows to automate the whole process of cash processing and collection operations, generate "Accompanying cash orders" for cash bags, report cards, create collection routes, monitor and control the work of teams of collectors on routes [8].

The collection software records the beginning/end of the working day of collectors, keeps track of electronic certificates checking, passing electronic service instruction by collectors before leaving for routes, generates the team of collectors, route numbers, number of collection points, fully automates the work of the duty collector.

The collection software carries out obligatory double-check of data entry that minimizes errors in the amounts of collection, banknote information, numbers of bags, requisites of the organizations, numbers of routes, or any other errors that may occur during work with ATM cassettes.

The software allows to keep records of collections and documents on several sales units/bank branches at one workplace as well as calculates and charges commissions for collection services, provided to customers, automatically generates invoices and acts of work performed [8].

The traditional method of collection causes a number of problems to all participants, including the high cost of manual cash processing, long time of crediting funds to the current account, the issue of safe money storage for collection, time, spent for documents preparation, difficulty in route planning and high road congestions, returns of collectors due to errors and shortcomings, uneven loading of the cash register.

These problems can be solved by an automated deposit machine (ADM), which can be used to deposit cash at any time 24/7 and allows to optimize routes, to reduce time and financial costs, eliminates errors, associated with filling out paper documents, required for traditional collection.

$\mathrm{ADM}$ is a compact automated deposit machine that allows to automatically receive cash, verify its authenticity, and to recalculate and store cash for collection. The deposit machine provides crediting of funds to the company's current account online within one minute, thus, allowing to reduce costs, increase security in cash processing, and perform the necessary financial operations for the business: pay salaries, taxes, conduct settlements with partners [9].

Some ADM models can hold up to 10-30 thousand banknotes, which allows postponing the physical unloading of cash for several days. After depositing money in ADM, the responsibility for their security passes to the collection unit. The diagnostic system remotely monitors the technical conditions of ADM and the level of cash deposit. Servicing time per one collection point is reduced by 2-3 times; collection can be done without recalculation of banknotes, filling out forms, and checking documents [9].

Innovative multifunctional ATMs with the function of banknote and coin recirculation are now widespread in Ukraine. The new cash processing technology allows the device to issue cash 
that have been deposited by other customers of the bank to replenish their accounts. This significantly reduces the need for periodic collection of the ATM and to the great extent eliminates the possibility of downtime when the ATM has run out of cash [10].

This is a new technological approach, which uses a new concept in the closed cash flow management system, a key element of which is innovation in banknote storage. For banks, this means optimizing cash replenishment and collection processes, reducing costs, and improving security. A closed cycle of cash turnover will take place within one recirculation system, which gives customers the opportunity to withdraw cash and top up their credit card or perform other banking operations.

Modern software systems for monitoring and managing ATMs, provide the ability to predict the optimal load of each device and each individual ATM network, reduce cash surpluses, predict a relevant number of collections to help avoid unnecessary departures of collectors, get information about the current balance, forecast the next downtime of ATMs without cash and other events at any time [10].

The Intelligent Banknote Neutralization System (IBNS) is a security device that protects valuables from unauthorized access by marking them as stolen with indelible dye when an attempt is made to attack collectors. The point is that criminals realize that the reward does not justify the existing risk. The use of the IBNS system is mandatory for collection in the European Union, where attacks on ATMs have decreased since its introduction [11].

An innovative cash collection system - special containers for collection, which in case of danger paint cash with special substance, helps to significantly increase the level of security in the transportation of valuables, improve the logistics of managing the collection process, optimize the costs of collection units for the protection of transported valuables. The container allows to carry from 6000 to 12000 banknotes [11].

The ICSD (In-Cassette Staining Device) system paints the banknotes of ATM cassettes, thus, actively protecting banknotes, placed in standard ATM cassettes, for cash recirculation from any physical attacks: rams, burglaries, robberies, thefts, explosives, gas.

Protection of valuables by encapsulation (foam) is an innovative system, controlled by a built-in electronic system, which is a new method of preserving valuables without damaging them. In the event of an attack, the valuables become inaccessible to criminals due to the leakage of special chemical foam, which instantly becomes a monolith [11].

Today, five foreign global collection CIT companies occupy almost $60 \%$ of the global collection market. The main players in the collection market abroad are large multinational companies with diversified businesses, working in the areas of cash collection and processing, postal items, and security [12].

Company Prosegur, which successfully operates in the US, Germany, and in the Latin American collection market, offers automated cash management solutions for business through the use of software Cash Today, developed on the basis of artificial intelligence technologies [13].

Cash storage terminals are used for accepting and storing cash in catering establishments and provide for independent deposit of banknotes and coins to this device as payment for the order made. The device will print a receipt, indicating the amount and date of the transaction; the deposited funds will be credited to the bank account of the institution. The collection service should just periodically collect the terminal by replacing the filled cash cassette with an empty one [13].

Prosegur is currently implementing one of its projects, which aims to introduce a single telemetry and geolocation system for its armored collection vehicles. Continuous real-time monitoring will help maximize the vehicle load on routes, improve safety, drive efficiency, reduce fuel consumption and overall costs [13].

The American company Brink's is a world leader in the field of general cash management, secure logistics and payment solutions, ATM collection services, cash management services, and international transportation of valuables, which is provided by the Total cash Management software for cash processing and collection [14]. 
Loomis collection company uses advanced software for ATM cash forecasting to optimize an institution's cash flow by analyzing its usage history to determine the amount of cash, needed to reduce balances, avoid cash withdrawals, and reduce staff working hours.

Loomis SafePoint software package combines advanced technologies and is specifically designed to reduce costs, improve the efficiency of cash collection and processing [15].

G4S has a leading position in the UK cash collection market and offers its customers a powerful software package Cash Solutions for cash processing and cash collection [16].

Studying the experience of economically developed countries, in particular transnational CIT companies, it is concluded, that their existing mechanisms of state regulation of the market for the provision of cash collection services are extremely important to address the challenges relevant today for the banking system of Ukraine.

The study of effective mechanisms of state regulation of the market for collection services, the experience of collection operations by economically developed countries, including large multinational collection companies, is extremely important to address the challenges relevant today for the banking system of Ukraine.

Central Bank of the country, as a leading state banking institution, which establishes norms and rules, determining the procedure for collection, and carries out state regulatory control over compliance with the rules and procedure for collection operations, must, given their extreme importance for the state economy, to conduct and develop scientific research in terms of conducting operations on collection, transportation of valuables, processing and protection of cash.

The issue of the effectiveness of state regulation of the collection market is a special factor in the safety of collection companies, as there is a direct link between the number of attacks on collectors and the use or non-use of firearms on routes, professional training and education of collectors.

That is why in future scientific research of collection operations, it is necessary to pay attention to ensuring a professional level of security on collection routes, achieving high profitability of such operations, analysis of the possibility of merging small collection units into one powerful state collection company.

\section{Conclusions}

The study shows the important role of modern information technologies and software products in the collection operations in the banking system of Ukraine. The transition to electronic collection operations contributes to solving of a number of problems inherent to the classic method of cash collection. The rapid development of modern information technologies stipulates the need to systematize scientific views on the latest banking information technologies and analyze their capabilities.

The appearance of modern innovative technologies, methods and special devices for working with cash and cash collection on the Ukrainian market requires radical changes in the system of training and education of collectors.

In order to achieve the goals of effective state regulation of the collection market, the central bank needs to establish and finalize certain permits that regulate the current procedure for collection operations in terms of electronic collection, training and preparation of collectors, information protection and safety during collection, legal possibility of functioning of foreign CIT companies in Ukraine.

The National Bank should initiate the adoption of the Law of Ukraine «On Collection», which would allow for effective regulation of the collection market as well as continue and improve research in the development of modern innovative information technologies in the field of collection services.

\section{References}

[1] Kompaniia BS/2, rishennia Cash Management.iQ. Available at: https://cashmanagementiq.com/2021/05/03/cash-managementiq-revolution-replatforming-of-cash-circulation-optimization-system Last accessed: 30.08.2021

[2] Sostoianie i perspektivy razvitiia NDO v Rossii (2020). Assotsiatsiia «NDO». Moscow: Pechatnii dom Ilinykh, 45. Available at: obzor_2020.pdf (a-ndo.ru) Last accessed: 27.09.2021 
[3] Pro Natsionalnyi bank Ukrainy (1999). Zakon Ukrainy No. 679-XIV. 20.05.1999. Available at: https://zakon.rada.gov.ua/laws/ show/679-14\#Text Last accessed: 30.08.2021

[4] Polozhennia pro vedennia kasovykh operatsii u natsionalnii valiuti v Ukraini (2017). Postanova Pravlinnia Natsionalnoho banku Ukrainy No. 148. 29.12.2017. Available at: https://zakon.rada.gov.ua/laws/show/v0148500-17\#Text Last accessed: 08.09.2021

[5] Instruktsiia $\mathrm{z}$ orhanizatsii inkasatsii koshtiv ta perevezennia valiutnykh tsinnostei u bankivskykh ustanovakh $\mathrm{v}$ Ukraini (2017). Postanova Pravlinnia Natsionalnoho banku Ukrainy No. 29. 31.03.2017. Available at: https:/zakon.rada.gov.ua/laws/ show/v0029500-17\#n8 Last accessed: 01.09.2021

[6] Torhovelna vyruchka. Inkasatsiia. PAT KB PryvatBank. Available at: http://privatbank.ua/business/universalnyje-reshenija/ torgovaya-viruchka/ Last accessed: 08.09.2021

[7] BS/2 Cash management. Available at: https://www.bs2.lt/ru/programmnoe-obespechenie/semeystvo-produktov-iq/cash-managementiq/ Last accessed: 08.09.2021

[8] Programno-aparatnii kompleks «Avtokasa». Available at: https://avtokassa.com/ Last accessed: 03.09.2021

[9] Avtomatyzovana depozytna mashyna. Kompaniia Renome Smart. Available at: https://renomesmart.com/hardware/es-3002/ Last accessed: 08.09.2021

[10] U ramkakh Alfa Jazz Fest Alfa-Bank ta Ukrsotsbank predstavliat novitni bankomaty (2017). Alfa-Bank. Available at: https:// alfabank.ua/about/press/u-ramkah-alfa-jazz-fest-alfa-bank-ta-ukrsocbank-predstavlyat-1360 Last accessed: 08.09.2021

[11] The future of ATM cash protection. Oberthur Cash Protection. Available at: https://blog.oberthurcp.com/future-of-atm-cashprotection Last accessed: 08.09.2021

[12] Cash-in-transit (CIT). Wikipedia. Available at: https://en.wikipedia.org/wiki/Cash-in-transit Last accessed: 08.09.2021

[13] Prosegur. Cash Today. Available at: https://www.prosegur.es/negocios-y-pymes/soluciones-efectivo/logistica-y-gestion Last accessed: 08.09.2021

[14] Brink's. Total cash Management. Available at: https://us.brinks.com/ Last accessed: 08.09.2021

[15] Cash in Transit. Loomis. SafePoint. Available at: https://www.loomis.us/services/cash-transit Last accessed: 08.09.2021

[16] G4S. Cash Solutions. Available at: https://www.g4s.com Last accessed: 08.09.2021

How to cite: Fedets, A. (2021). Improving the efficiency of cash collection operations with the help of modern information technologies. EUREKA: Social and Humanities, 5, 49-57. doi: http://doi.org/10.21303/2504-5571.2021.002078 